\title{
PCR-based gut content analysis to identify arthropod predators of Haplodiplosis marginata
}

by Rowley, C., Cherrill, A.J., Leather, S.R., McCormack, A., Skarp, J.E. and Pope, T.W.

Copyright, Publisher and Additional Information: This is the author accepted manuscript. The final published version (version of record) is available online via Elsevier Please refer to any applicable terms of use of the publisher.

DOI: https://doi.org/10.1016/j.biocontrol.2017.10.003

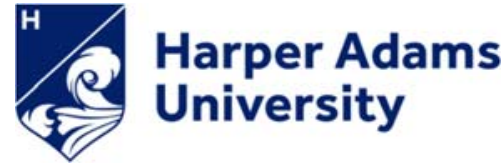


4 Charlotte Rowley ${ }^{1 *}$, Andrew J. Cherrill ${ }^{1}$, Simon R. Leather ${ }^{1}$, Alexander W. McCormack ${ }^{1}$, 5 Janetta E. Skarp², \& Tom W. Pope ${ }^{1}$

6

$7 \quad{ }^{1}$ Centre for Integrated Pest Management, Harper Adams University, Newport, Shropshire 8 TF10 8NB, UK

$9 \quad{ }^{2}$ Imperial College London, Kensington, London SW7 2AZ, UK

\section{PCR-based gut content analysis to identify arthropod predators of Haplodiplosis} marginata

\section{0}

${ }^{*}$ Correspondence: Charlotte Rowley, Centre for Integrated Pest Management, Harper Adams University, Newport, Shropshire TF10 8NB, UK. E-mail: crowley@harper-adams.ac.uk

Keywords Natural enemies, IPM, cereals, primers, Cecidomyiidae

Running Title PCR-based H. marginata gut content analysis

\section{Abstract}

Saddle gall midge (Haplodiplosis marginata) is a cereal pest exhibiting sporadic outbreaks for which chemical control options are limited. Integrated Pest Management programs may offer a means of suppressing $H$. marginata outbreaks, reducing pesticide input. Many IPM programs benefit from the natural population suppression inflicted through predation and parasitism. The larval stage of $H$. marginata overwinters in the soil and may be preyed upon by ground-dwelling arthropods, however the natural enemies of $H$. marginata remain unrecognized. A PCR-based assay for detecting $H$. marginata in the guts of predators was designed using novel species-specific primers. Feeding trials involving $H$. marginata larvae showed a detectability half-life of 31.07 hours post-feeding in Nebria brevicollis. The guts of field-caught Carabidae were screened for H. marginata DNA. Four species: Poecilus 
versicolor, Nebria brevicollis, Harpalus rufipes and Loricera pilicornis were identified as natural enemies of $H$. marginata for the first time. A higher proportion of positive results were obtained at the end of $H$. marginata emergence (July) compared to the beginning (May). The importance of understanding trophic interactions in the management of $H$. marginata is discussed in addition to the potential uses for the newly designed assay and primers.
1. Introduction

Saddle gall midge Haplodiplosis marginata (Diptera: Cecidomyiidae) (von Roser) is a pest of cereals that has been the focus of relatively little research in Europe due to the sporadic nature of outbreaks. Recent outbreaks in the United Kingdom and elsewhere have highlighted gaps in knowledge regarding the best options for its control and long-term management. Recent reviews have consolidated existing literature on the biology and ecology of this insect (Censier et al., 2015; Rowley et al., 2016). Briefly, H. marginata is a univoltine insect that overwinters in the larval stage. Adults emerge in late April through May and oviposit on the leaves of cereals and grasses (Censier et al., 2015; Rowley et al. 2016). Newly hatched larvae then feed on the stem of the plant until maturity, forming saddleshaped galls in the process (Golightly \& Woodville, 1974). The larvae then drop from the plant in late July and burrow down into the soil to enter diapause, which can extend to more than one year when environmental conditions are not conducive for pupation to occur in spring (Nijveldt \& Hulshoff, 1968). Gall formation on the stems of cereal plants can lead to inhibition of growth and yield loss, as well as increasing the risk of pathogen attack and stem breakage (Nijveldt \& Hulshoff, 1968; Woodville, 1970; Golightly, 1979; Popov et al., 1998). Application of pyrethroid insecticides, timed to coincide with adult emergence or the egg laying stage, can be effective against this pest (Ellis et al., 2014). Later applications may be ineffective as larvae are protected from the insecticide by the leaf sheath whilst feeding 
55 (Gratwick, 1992). It is widely accepted, however, that an over-reliance on chemical

56 pesticides is undesirable due to detrimental effects on human health and the environment

57 (Aktar et al., 2009; Geiger et al., 2010). In particular, pesticides such as pyrethroids can

58 have a negative impact on non-target organisms such as carabids (Holland \& Luff, 2000; van

59 Toor, 2006). Integrated Pest Management (IPM) programmes aim to employ control

60 measures that minimise the impact on the wider environment (Kogan, 1998) and are

61 promoted by the EU Sustainable Use of Pesticides Directive as a means of minimising

62 chemical inputs in pest management (Directive 2009/128/EC). Such programs are based on

63 decision support systems that rely on knowledge of the biology and ecology of the target

64 organism, including interactions with other organisms in the crop environment (Kogan, 1998).

65 One strategy that may be adopted in IPM programs is to increase pest mortality from natural 66 enemies through conservation or augmentative biological control (Naranjo, 2001; Östman et

67 al., 2003). Currently, the impact of predation on $H$. marginata population dynamics is poorly

68 understood and there is a clear lack of information on the natural enemies of this insect (see

69 below). Such knowledge would greatly benefit decision making in IPM programmes aimed at 70 this pest.

71

72 Predatory interactions involving invertebrates in the field can be difficult to study, often being

73 short-lived, inconspicuous, and unobservable without intervention (Stuart \& Greenstone,

74 1990; Symondson, 2002). The problems are exacerbated with belowground interactions

75 (Juen \& Traugott, 2004) which has led to a distinct lack of information on the arthropod

76 species that prey on primarily soil dwelling species such as $H$. marginata. An important

77 component of IPM programs is an understanding of the impact of natural enemies on pest

78 populations. In many cases, effective maintenance of natural enemy assemblages can help

79 to suppress pest populations (Symondson et al., 2002; Wilby \& Thomas, 2002; Cardinale et

80 al., 2003). This is generally achieved by increasing numbers of existing predator populations

81 either artificially through introductions (augmentative biological control) or naturally through 
beneficial environmental practices (conservation biological control). Generalist predators are potentially less effective against dipteran pests due to a large proportion of their life cycle being belowground or within the host plant (Symondson et al., 2002). Nonetheless, the presence of natural enemies has been shown to impact dipteran pests such as brassica pod midge (Büchs \& Nuss, 2000), onion maggot (Grafius \& Warner, 1989) and cabbage root fly (Mowat \& Martin, 1981).

Larvae of Haplodiplosis marginata are most vulnerable to predation in April and early May, when they move towards the soil surface to pupate, and in July and August, when mature larvae drop from the plant to the soil. Predation of the larvae of another Cecidomyiid, orange wheat blossom midge Sitodiplosis mosellana (Géhin), by Carabidae and Staphylinidae is thought to occur in the soil stage (Speyer \& Waede, 1956), during pupation (Floate et al., 1990) and on return to the soil to overwinter (Basedow, 1973; Holland \& Thomas, 2000). Generalist arthropod predators active during these periods could therefore be exploited to enhance the suppressive effects of regular crop rotations as a means of reducing the frequency and severity of $H$. marginata outbreaks.

Current information on natural enemies of $H$. marginata or associated mortality at any life stage is limited. The parasitoids Chrysocharis amyite (Walker) and various Platygaster spp. are known to attack $H$. marginata larvae, but they have little impact on overall population size (Nijveldt \& Hulshoff, 1968; Baier, 1963; Skuhravý, 1982; Rowley et al., 2016). As with S. mosellana, Carabidae and Staphylinidae have been reported to prey on larvae of $H$. marginata, however, field observations are scarce and the exact species remain unidentified (Golightly \& Woodville, 1974; Skuhravý et al., 1993). Nothing is known about the species that prey on adults. A study in Canada identified 14 species of carabid preying on S. mosellana in the field (Floate et al., 1990). This study utilized immunological markers to identify evidence of predation from gut content analysis. In the past two decades, PCR- 
based molecular gut analysis has been developed as an alternative to immunological assays

110 to identify predation through the detection of target organism DNA in the guts of predators

111 (Chen et al, 2000; Symondson, 2002; Gariepy et al., 2007). Given the relatively quick, cheap

112 and easily reproducible nature of this technology it has become a widespread and reliable

113 means of detecting trophic interactions in the field. PCR-based gut assays have been used

114 extensively in agroecosystems to identify the natural enemies of pest species such as cereal

115 aphids (Chen et al., 2000), western corn rootworm (Lundgren et al., 2009), cotton whitefly

116 (Zhang et al., 2007), slugs (Hatteland et al., 2011), and pollen beetle (Öberg et al. 2011),

117 including multiplex reactions with multiple target pest species (Harper et al., 2005; King et al.,

118 2010). The method is highly suited to predator surveys such as this; where prey spend a

119 large proportion of the time belowground, making observational studies impossible. Despite

120 the potential for increased false negatives from soil contamination (Juen \& Traugott, 2006)

121 this technique has been used successfully to identify trophic interactions of belowground

122 species in the field (Eitzinger et al., 2013).

123

124 Here, we describe the development of species-specific primers for $H$. marginata for use in a

125 PCR-based gut assay. A field survey of natural enemies of $H$. marginata in the UK using the 126 assay identifies predators of this insect to species level for the first time. Knowledge of the

127 key species that prey on the larval stage of this insect will help to inform decisions aimed at

128 encouraging populations of beneficial insects as a means of aiding pest population

129 suppression. This work may also lead to future applications of molecular techniques in

130 further research efforts on this relatively understudied cereal pest.

131

132 2. Methods

133

$134 \quad 2.1 \quad$ Insects 
Haplodiplosis marginata larvae were collected from fields in Oxfordshire $\left(51^{\circ} 55^{\prime \prime N}, 1^{\circ} 10^{\prime \prime} \mathrm{W}\right)$ and Buckinghamshire $\left(51^{\circ} 37 " \mathrm{~N}, 0^{\circ} 48 \mathrm{~W}\right)$, UK, between April and June 2015. Larvae were maintained in plastic containers of moist, sterilised compost at $4^{\circ} \mathrm{C}$ until use. Adult Nebria brevicollis (Coleoptera: Carabidae) (Fabricius) beetles were collected in pitfall traps at Harper Adams University, UK, in June 2015. Beetles were maintained in clear plastic containers at $20^{\circ} \mathrm{C}, 16: 8 \mathrm{~L}: \mathrm{D}, 60 \% \mathrm{RH}$ and fed on Tenebrio molitor (Coleoptera: Tenebrionidae) (Linnaeus) larvae prior to the feeding assay. Insect specimens used in cross-reactivity tests were collected by hand (Harper Adams University), pitfall traps and pan traps (Oxfordshire) and stored at $-80^{\circ} \mathrm{C}$ prior to DNA extraction.

\subsection{DNA Extraction}

146 DNA was extracted using a DNeasy Blood and Tissue Kit (Qiagen, Hilden, Germany) in accordance with the manufacturer's supplementary protocol for insect DNA extraction. Whole insect specimens were washed in Tris-EDTA (TE) buffer prior to extraction, followed by grinding with a sterile micro-pestle. Single whole $H$. marginata larvae and undissected

150 invertebrates were used for sequencing and assay cross-reactivity testing. For gut analyses,

151 the elytra of the beetles were removed and entire guts were dissected out, before being used

152 for DNA extraction. Following extraction, DNA was pelleted by centrifugation and

153 resuspended in $100 \mu \mathrm{L} \mathrm{TE}$ buffer before being stored at $-20^{\circ} \mathrm{C}$ until use. One negative 154 control (no insect material) was included for every 20 extractions.

155

1562.3 PCR amplification and sequencing of $H$. marginata $\mathrm{COI}$ region

157 A $521 \mathrm{bp}$ fragment of $H$. marginata DNA from the mitochondrial cytochrome oxidase subunit I

158 (COI) gene was amplified using the universal insect primers C1-J-1718 and C1-N-2191

159 (Simon et al., 1994; King et al., 2010). Individual PCR reactions (25 $\mu \mathrm{L}$ ) comprised of; $1 \mathrm{X}$ 160 PCR master mix (Invitrogen, Carlsbad, CA, USA), $0.625 \cup$ Taq polymerase (Invitrogen), 4 $161 \mathrm{mM} \mathrm{MgCl} 2$ (Invitrogen), $2.5 \mu \mathrm{g}$ bovine serum albumin (Sigma-Aldrich, Dorset, UK), $0.05 \mathrm{mM}$ 
$162 \mathrm{dNTPs}$ (Invitrogen), $0.1 \mu \mathrm{M}$ of each primer and $2.5 \mu \mathrm{L}$ of target DNA. PCR conditions

163 consisted of an initial denaturation at $94^{\circ} \mathrm{C}$ for $2 \min 30 \mathrm{~s}$, then 35 cycles of $94^{\circ} \mathrm{C}$ for $30 \mathrm{~s}$,

$16450^{\circ} \mathrm{C}$ for $30 \mathrm{~s}$ and $72^{\circ} \mathrm{C}$ for $45 \mathrm{~s}$, followed by a final extension period at $72^{\circ} \mathrm{C}$ for $10 \mathrm{~min}$.

165 PCR products were separated on a $1.5 \%$ agarose gel stained with GelRed ${ }^{\mathrm{TM}}$ Nucleic Acid

166 Gel Stain (Biotium, Fremont, USA) and photographed under UV light (Sint et al., 2011).

167 Unpurified PCR products were sequenced by Eurofins Genomics (Ebersberg, Germany) on a

168 3730xI DNA analyzer (Applied Biosystems, Foster City, CA, USA). Sequences were

169 deposited in the European Nucleotide Archive (accession number LT852755).

170

$171 \quad 2.4 \quad$ Primer design and PCR assay development

172 Primers specific to $H$. marginata were designed from the sequencing products using the 173 program Primer-BLAST (Geer et al., 2010). Individual primer pairs were synthesised by

174 Eurogentec Ltd. (Liège, Belgium) and validated for use using a T100 Thermal Cycler (Bio-

$175 \mathrm{rad}$, Watford, UK). Validation of the primer pairs consisted of specificity testing against $H$.

176 marginata and 40 non-target organisms from orders Diptera, Coleoptera, Hymenoptera,

177 Hemiptera, and Araneae (Table 1). PCR reactions proceeded as described in section 2.3.

178 Following this the primer pairs showing no cross-reactivity were selected and the optimum

179 PCR conditions examined by altering the annealing temperature across individual reactions

180 (55 ${ }^{\circ} \mathrm{C}$ to $77^{\circ} \mathrm{C}$ ) observing for a strong single band. The primer pair with the highest optimum

181 annealing temperature was selected for use in the assay. Assay sensitivity was determined

182 using a serial dilution of $H$. marginata DNA at concentrations from $10 \mathrm{ng} \mu \mathrm{L}^{-1}$ to $0.0001{\mathrm{ng} \mu \mathrm{L}^{-}}^{-}$

$183{ }^{1}$, with 10 replicates of each dilution.

184

1852.5 Rate of digestion of $H$. marginata DNA in predator guts

186 The digestion half-life of $H$. marginata DNA in the guts of a predator was determined under

187 controlled conditions using the carabid N. brevicollis. The half-life is the time at which $H$.

188 marginata DNA can only be detected in $50 \%$ of the predators following feeding (Greenstone 
189 \& Hunt, 1993). Prior to feeding, N. brevicollis specimens were separated into individual clear 190 plastic containers (10 cm diameter $\times 6 \mathrm{~cm}$ height) with moist cotton wool and starved for 5 191 days to ensure guts were empty prior to the experiment. A single live larva of $H$. marginata 192 was placed into each container at time $0 \mathrm{~h}$ and beetles were observed feeding. Beetles that 193 did not consume the larva within 15 minutes were excluded from the experiment. Beetles 194 were maintained at $20^{\circ} \mathrm{C}, 16: 8 \mathrm{~L}: \mathrm{D}, 60 \% \mathrm{RH}$ for the duration of the trial. Groups of beetles 195 were killed by freezing at $0 \mathrm{~h}, 2 \mathrm{~h}, 4 \mathrm{~h}, 8 \mathrm{~h}, 12 \mathrm{~h}, 24 \mathrm{~h}$ and $36 \mathrm{~h}$ post-feeding. All groups 196 comprised 10 beetles with the exception of the $24 \mathrm{~h}$ group which had 9 beetles. Five beetles 197 were left unfed and killed at $0 \mathrm{~h}$. All specimens were stored at $-80{ }^{\circ} \mathrm{C}$ and entire guts were 198 dissected from each beetle prior to DNA extraction (see section 2.2). PCR reactions 199 proceeded as described in section 2.3. Positive results were expressed as a percentage of 200 the total insects screened at each time point and a probit model was fitted to the data to 201 determine the time post-feeding at which the detection half-life occurred (Greenstone et al., 202 2014). Statistical analysis was performed in R v.3.3.1 (R Core Team, 2016).

203

\subsection{Field survey}

205 Carabidae were collected using live pitfall traps from the field in Oxfordshire which was 206 planted with spring wheat. Five pitfall traps were positioned in a cross-shaped array 207 connected with barriers $(10 \mathrm{~cm} \mathrm{~h} \times 30 \mathrm{~cm} \mathrm{I})$ made from galvanised lawn edging to improve 208 the catch rate (Hansen \& New, 2005). Each trap was comprised of a plastic beaker $(8 \mathrm{~cm}$ 209 diameter $\times 10.6 \mathrm{~cm}$ height) with small rocks placed in the bottom as refugia (Sunderland et 210 al., 2005). A corrugated plastic cover $(12 \mathrm{~cm} \times 12 \mathrm{~cm})$ on wire supports was positioned $5 \mathrm{~cm}$

211 above the trap. On each sampling date, six arrays were set up making 30 traps in total, 212 positioned in various field locations with at least $30 \mathrm{~m}$ between arrays. Traps were set in the 213 late afternoon or early evening and collected before noon on the following day. Live 214 specimens were immediately placed on ice at the point of collection, prior to storage at -80 
${ }^{\circ} \mathrm{C}$. Trapping took place in early May 2016 on 2 occasions, 10 days apart, with an additional collection made in late July using just 20 traps (4 arrays).

217

218

\section{Results}

\subsection{Primer design and PCR assay development}

The selected primer pair amplified a fragment of 348bp and had an optimum annealing temperature of $65^{\circ} \mathrm{C}$ which was used for all subsequent reactions. The sequences of the selected primers were as follows: F-COI-12 5'-GAGCACCAGATATAGCATTTCC and R-COI360 5'-CCAGCCAATACTGGTAAAGAAAG. No cross-reactivity of the primers was observed with any of the non-target species tested, which included representative individuals from 8 different orders including the Cecidomyiid S. mosellana. Using the newly designed primers,

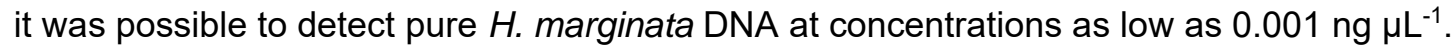

\subsection{Rate of digestion of H. marginata DNA in predator guts}

Digestion time had a significant effect on the probability of detecting $H$. marginata DNA from the guts of $N$. brevicollis $\left(F_{1,5}=16.297, P<0.01\right)$. The detectability half-life of $H$. marginata

DNA in this scenario was determined to be $31.07 \mathrm{~h}$ (Figure 1). The assay was successful in $100 \%$ of individuals killed immediately after feeding, while the unfed beetles did not produce any positive results. The greatest decline in probability of detection in the time points tested occurred between $12 \mathrm{~h}$ and $24 \mathrm{~h}$ post-feeding.

\subsection{Field survey}

237 From all trapping occasions, 110 individual carabid specimens of 11 different species were 238 trapped. The majority of beetles (47\%) were caught in the central traps of the arrays. Positive results for the presence of $H$. marginata DNA were found in $7.2 \%$ of specimens and were obtained from 4 different species (Table 2). Beetles trapped late in the season (July)

241 represented only $15 \%$ of all specimens tested, but had a much higher rate of positive results 
$242(23.5 \%)$ compared to beetles trapped in May (4.3\%). This is despite the activity density of

243 the beetles being almost identical in May and July ( 0.84 and 0.85 beetles per trap per day

244 respectively).

245

246

4. Discussion

247 The development of species-specific primers for $H$. marginata, as described here, increases

248 the potential for research on this cryptic insect at a molecular level. Here, we have applied

249 this to the development of a viable gut analysis assay, enabling highly specific and reliable

250 detection in the guts of predatory natural enemies. The field survey has identified four

251 carabid species feeding on this pest in the wild for the first time, with implications for its

252 effective management.

253

254 The COI region of the genome is commonly used for species-specific primer design as it is

255 less highly conserved than other regions (King, 2008). It is particularly appropriate for gut

256 analysis studies as it is located in the mitochondria, therefore each cell will have multiple

257 copies making the probability of detection greater than for nucleic DNA (Hoy, 1994). The

258 target amplicon is $348 \mathrm{bp}$, which slightly exceeds the recommended maximum length of

$259300 \mathrm{bp}$ (King et al., 2008) based on the idea that shorter fragments will be subject to less

260 digestion in the gut. The work done by Sint et al. (2011) however, suggests that this

261 recommendation might be too conservative. For example, Juen and Traugott (2006) found

262 no difference in the amplification success of 463bp and $127 \mathrm{bp}$ amplicons of Amphimallon

263 solstitiale (Linnaeus) DNA in the guts of Poecilus versicolour (Sturm) larvae. Furthermore,

264 no significant relationship was found between fragment length and the detectability half-life

265 taken from a range of studies (Greenstone et al., 2014). The primers described here

266 performed well at a high annealing temperature of $65^{\circ} \mathrm{C}$ which reduces the chance of

267 erroneous base matching at the primer sites (King, 2008), but was not the highest

268 temperature at which an amplicon was obtained to ensure the sensitivity of the assay (Sint et 
al., 2011). The specificity of the assay was supported by the lack of cross reactivity with

270 DNA from non-target species commonly found on agricultural land including the Cecidomyiid

271 S. mosellana.

272

273 The assay was able to reliably detect $H$. marginata DNA at concentrations of $0.001 \mathrm{ng} \mu \mathrm{L}^{-1}$

274 which is comparable to other insect primers used in gut analysis (e.g. Ekbom et al., 2014).

275 The effects of digestion or inhibitors present in the guts of the predator may further reduce

276 assay sensitivity in some instances. Nonetheless, the ability of the assay to detect the DNA

277 from a single $H$. marginata larva in starved predator guts was repeatedly demonstrated in the

278 feeding assay giving confidence in the reliability of the test. The feeding assay further

279 demonstrated that the half-life of detection for this assay was $31 \mathrm{~h}$ post-consumption, which

280 is comparable to assays for other predator-prey interactions (e.g. Juen \& Traugott, 2004,

281 Waldner et al., 2013) and is well within the range so far reported for other carabids of 18 -

$28288.5 \mathrm{~h}$ (Monzó et al., 2011). A long detectability half-life is vital if the assay is to be used on

283 field-caught specimens particularly when predators are mainly nocturnal, as with many

284 carabids (Kromp, 1999). The results suggest the assay was more than adequate for the field

285 survey described here where traps were in place for no more than $18 \mathrm{~h}$. Additionally, the

286 feeding trial was conducted at $20^{\circ} \mathrm{C}$ which is higher than typical field temperatures, and may

287 reflect an underestimation of detection half-life in the field (Hoogendoorn \& Heimpel, 2001).

288 The carabid species used in this trial, N. brevicollis, is a common predator in arable

289 environments (Luff, 2007) however detection half-life will vary depending on the predator

290 species (Greenstone et al., 2007). For example, the detectability of aphid DNA was higher in

291 N. brevicollis compared to another common carabid, Pterostichus melanarius (Illiger),

292 independent of the effects of ambient temperature or target amplicon size (von Berg et al.,

293 2008). Detectability appears to vary less between species of the same taxa than between

294 taxa however (Waldner et al., 2013), which suggests that the data shown here represent a

295 reasonable benchmark for carabids of a similar size. Detection half-life can, however, vary 
between life stages of the same species (Ingels et al., 2013) and therefore further work will

need to be done to extend this assay to predatory carabid larvae.

298

This field survey shows for the first time the species of carabid beetle that are feeding on $H$. marginata. Of the 12 species caught on the surveyed site, four tested positive for the presence of $H$. marginata DNA. All of the species which tested positive are relatively common, highly generalist feeders of medium to large size (above $5 \mathrm{~mm}$ long). A number of these species are known to prey on dipteran adults and larvae (Penney, 1966; Allen \& Hagley, 1990; Lys, 1995; Sunderland et al., 1995; Luff, 2002; King et al. 2010) and species identified as predators of S. mosellana in Canada belong to two of the genera identified as containing predators of $H$. marginata in this study (Floate et al., 1990). Although many species display burrowing behaviours, belowground predation by adult carabids has not been well studied. Many carabid larvae are active belowground predators (Lövei \& Sunderland, 1996) and have been shown to feed on S. mosellana in the field (Floate et al., 1990). While not surveyed here, they are potentially a significant source of predation for $H$. marginata larvae. The proportion of positive assays was higher in July, despite the activity

312 density being comparable between early and late season sampling. Drier soil in the late 313 season may have prevented $H$. marginata from burrowing into the soil, or enabled carabids easier access to larvae belowground via the formation of fissures. Basedow (1973) reported from field observations of the Cecidomyiids Dasineura brassicae (Winnertz), Contarinia tritici

316 (Kirby) and S. mosellana mortalities of up to $65 \%, 58 \%$ and $43 \%$ respectively from predation

317 of larvae returning to the soil to overwinter. This was supported by the findings of Floate et 318 al., (1990) and Holland \& Thomas (2000) who found that larvae were more likely to be 319 preyed upon when returning to the soil to overwinter rather than during pupation. The results presented here suggest that the same is true of $H$. marginata larvae. 
322 As with other predator surveys using PCR-based gut analysis, there is the chance that a

323 positive result could have resulted from scavenging or secondary predation of adult or larval

324 H. marginata (Juen \& Traugott, 2004; Foltan et al., 2005; Sheppard et al., 2005). Carabid

325 beetles frequently exhibit intraguild predation (Snyder \& Wise, 1999; Lang, 2002) and will

326 feed on carrion, sometimes in preference to fresh prey (Mair \& Port, 2001; Foltan et al.,

327 2005). In this scenario, the surveyed predators will not be affecting $H$. marginata populations

328 directly, and may indirectly benefit them by consuming pest predators. Partially decayed

329 organisms are harder to detect in the gut however (Foltan et al., 2005), therefore it seems

330 reasonable to assume the positive results obtained here are as a result of predation. This

331 has implications for pest management, as these predatory arthropods could be contributing

332 to suppression of $H$. marginata populations. As pitfall traps are only effective at sampling

333 surface active arthropods, of which only carabids were surveyed here, the actual range of

334 organisms preying on $H$. marginata could be much larger. Dipteran larvae are a primary food

335 source of Staphylinidae (Good \& Giller, 1991) and dipteran species are an important dietary

336 component for many spiders (Harwood et al., 2007; Schmidt et al., 2012).

337

338 The primers developed for this study provide a useful resource for further molecular research

339 on this insect. They could be used in the identification of this species in traps, which is

340 particularly useful when specimens are partial or degraded (Frey et al., 2004). This could be

341 of value not only in monitoring tools, but also in expanding current knowledge on the

342 distribution of $H$. marginata in the UK which at present is based on limited data (Rowley et

343 al., 2016). The assay described here could also be used as a tool in field-based predation

344 experiments (Furlong, 2015) or included in multiplex PCRs to simultaneously screen for

345 many pest species at once (King et al., 2010). The detectability half-life of DNA in the guts of

346 fluid feeders such as centipedes, heteropterans and spiders is generally much longer than

347 that described in carabids (Harwood et al 2007; Greenstone et al 2007; Waldner et al.,

348 2013), therefore we are confident that this assay would be suitable for use in other predator 
taxa. Such surveys could reveal further trophic links involving $H$. marginata in agroecosystems which are at present unknown. These primers could also be used to investigate parasitoid enemies of $H$. marginata (Rougerie et al., 2011), providing information to further enhance pest management strategies. The field survey identifies for the first time, species which consume $H$. marginata in the field. Different rates of digestion and therefore

354 prey DNA degradation between species means that further data are required to quantify

355 rates of predation on $H$. marginata. The next step would be to obtain species-specific

356 digestibility data under controlled conditions and conduct further field surveys to identify the

357 most important predators of this pest. Quantification of predator density should be made

358 alongside such surveys to further inform potential biological control strategies. Similarly,

359 surveys should be extended over wider spatial and temporal scales to provide a more

360 comprehensive assessment of $H$. marginata natural enemies. Nonetheless, the information

361 presented here is vital in the management of this pest as it demonstrates that these and

362 other species of arthropod predators are likely to be having an impact on $H$. marginata

363 populations. This represents an important first step in understanding the predation pressures exerted on $\mathrm{H}$. marginata populations, which may be a key aspect in the development of an effective IPM program for this insect.

\section{Acknowledgements}

This work was funded by AHDB Cereals and Oilseeds [Project number 214-0002].

\section{References}

AHDB Cereals \& Oilseeds. (2016). Orange Wheat Blossom Midge. Information Sheet 53, Agriculture and Horticulture Development Board, Kenilworth, UK.

Aktar, M. W., Sengupta, D., \& Chowdhury, A. (2009). Impact of pesticides use in agriculture: their benefits and hazards. Interdisciplinary Toxicology, 2(1), 1-12. https://doi.org/10.2478/v10102-009-0001-7 
Allen, W. R., \& Hagley, E. A. C. (1990). Epigeal Arthropods as Predators of Mature Larvae and Pupae of the Apple Maggot (Diptera: Tephritidae). Environmental Entomology, 19(2), 309-312. https://doi.org/10.1093/ee/19.2.309

Baier, M. (1963). Zur Biologie und Gradologie der Sattelmücke Haplodiplosis equestris Wagner (Diptera, Cecidomyiidae). Zeitschrift Für Angewandte Entomologie, 53(1-4), 217273. https://doi.org/10.1111/j.1439-0418.1963.tb02895.x

Basedow, T. (1973). The influence of predatory arthropods of the soil surface on the abundance of phytophagous insects in agriculture. / Der Einfluss epigaischer Raubarthropoden auf die Abundanz phytophager Insekten in der Agrarlandschaft. Pedobiologia, 13, 410-422.

Berg, K. von, Traugott, M., Symondson, W. O. C., \& Scheu, S. (2008). The effects of temperature on detection of prey DNA in two species of carabid beetle. Bulletin of Entomological Research, 98(3), 263-269. https://doi.org/10.1017/S0007485308006020

Bianchi, F. J. J. A., Booij, C. J. H., \& Tscharntke, T. (2006). Sustainable pest regulation in agricultural landscapes: a review on landscape composition, biodiversity and natural pest control. Proceedings of the Royal Society of London B: Biological Sciences, 273(1595), 1715-1727. https://doi.org/10.1098/rspb.2006.3530

Büchs, W., \& Nuss, H. (2000). First steps to assess the importance of epigaeic active polyphagous predators on oilseed rape insect pests with soil pupating larvae. IOBC-WPRS Bulletin, 23(6), 151-163.

Cardinale, B. J., Harvey, C. T., Gross, K., \& Ives, A. R. (2003). Biodiversity and biocontrol: emergent impacts of a multi-enemy assemblage on pest suppression and crop yield in an agroecosystem. Ecology Letters, 6(9), 857-865. https://doi.org/10.1046/j.14610248.2003.00508.x

Censier, F., De Proft, M., \& Bodson, B. (2015). The saddle gall midge, Haplodiplosis marginata (von Roser) (Diptera: Cecidomyiidae): Population dynamics and integrated management. Crop Protection, 78, 137-145. https://doi.org/10.1016/j.cropro.2015.09.002

Censier, F., Heuskin, S., San Martin Y Gomez, G., Michels, F., Fauconnier, M.-L., De Proft, M., Lognay, G.C., \& Bodson, B. (2016). A pheromone trap monitoring system for the saddle gall midge, Haplodiplosis marginata (von Roser) (Diptera: Cecidomyiidae). Crop Protection, 80, 1-6. https://doi.org/10.1016/j.cropro.2015.10.024

Chen, Y., Giles, K. L., Payton, M. E., \& Greenstone, M. H. (2000). Identifying key cereal aphid predators by molecular gut analysis. Molecular Ecology, 9(11), 1887-1898.

Davey, J. S., Vaughan, I. P., Andrew King, R., Bell, J. R., Bohan, D. A., Bruford, M. W., Holland, J.M., \& Symondson, W. O. C. (2013). Intraguild predation in winter wheat: prey choice by a common epigeal carabid consuming spiders. Journal of Applied Ecology, 50(1), 271-279. https://doi.org/10.1111/1365-2664.12008

Desneux, N., Decourtye, A., \& Delpuech, J.-M. (2007). The sublethal effects of pesticides on beneficial arthropods. Annual Review of Entomology, 52, 81-106.

https://doi.org/10.1146/annurev.ento.52.110405.091440 
Eitzinger, B., Micic, A., Körner, M., Traugott, M., \& Scheu, S. (2013). Unveiling soil food web links: New PCR assays for detection of prey DNA in the gut of soil arthropod predators. Soil Biology and Biochemistry, 57, 943-945. https://doi.org/10.1016/j.soilbio.2012.09.001

Ekbom, B., Kuusk, A.-K., Malsher, G., Åström, S., \& Cassel-Lundhagen, A. (2014). Consumption of flea beetles (Phyllotreta, Coleoptera: Chrysomelidae) by spiders in field habitats detected by molecular analysis. The Canadian Entomologist, 146(6), 639-651. https://doi.org/10.4039/tce.2014.14

439

440

441

442

443

444

445

446

447

448

449

450

451

452

453

454

455

456

457

458

459

460

461

462

463

464

465

466

467

468

469

470

471

472

473

474

475

476

477

478

479

480

481

482

483

Ellis, S., Ashlee, N. J., \& Maulden, K. A. (2014). Improving risk assessment and control of saddle gall midge (Haplodiplosis marginata). Aspects of Applied Biology, 127, 29-34.

Floate, K. D., Doane, J. F., \& Gillott, C. (1990). Carabid predators of the wheat midge (Diptera: Cecidomyiidae) in Saskatchewan. Environmental Entomology, 19(5), 1503-1511.

Foltan, P., Sheppard, S., Konvicka, M., \& Symondson, W. O. C. (2005). The significance of facultative scavenging in generalist predator nutrition: detecting decayed prey in the guts of predators using PCR. Molecular Ecology, 14(13), 4147-4158. https://doi.org/10.1111/j.1365294X.2005.02732.x

Frey, J. E., Frey, B., \& Baur, R. (2004). Molecular identification of the swede midge (Diptera: Cecidomyiidae). The Canadian Entomologist, 136(6), 771-780. https://doi.org/10.4039/n03120

Furlong, M. J. (2015). Knowing your enemies: Integrating molecular and ecological methods to assess the impact of arthropod predators on crop pests. Insect Science, 22(1), 6-19. https://doi.org/10.1111/1744-7917.12157

Gariepy, T. D., Kuhlmann, U., Gillott, C., \& Erlandson, M. (2007). Parasitoids, predators and PCR: the use of diagnostic molecular markers in biological control of Arthropods. Journal of Applied Entomology, 131(4), 225-240. https://doi.org/10.1111/j.1439-0418.2007.01145.x

Geiger, F., Bengtsson, J., Berendse, F., Weisser, W. W., Emmerson, M., Morales, M.B., ... Inchausti, P. (2010). Persistent negative effects of pesticides on biodiversity and biological control potential on European farmland. Basic and Applied Ecology, 11(2), 97-105.

https://doi.org/10.1016/j.baae.2009.12.001

Golightly, W. H. (1979). Saddle gall midge. London, UK: Ministry of Agriculture, Fisheries and Food.

Golightly, W. H., \& Woodville, H. C. (1974). Studies of recent outbreaks of saddle gall midge. Annals of Applied Biology, 77(1), 97.

Good, J. A., \& Giller, P. S. (1991). The diet of predatory staphylinid beetles-a review of records. Entomologist's Monthly Magazine, (127), 77-89.

Grafius, E., \& Warner, F. W. (1989). Predation by Bembidion quadrimaculatum (Coleoptera: Carabidae) on Delia antiqua (Diptera: Anthomyiidae). Environmental Entomology, 18(6), 1056-1059. https://doi.org/10.1093/ee/18.6.1056

Gratwick, M. (1992). Saddle gall midge. Crop Pests in the UK (pp. 306-309). London, UK: Chapman \& Hall. 
484

485

486

487

488

489

490

491

492

493

494

495

496

497

498

499

500

501

502

503

504

505

506

507

508

509

510

511

512

513

514

515

516

517

518

519

520

521

522

523

524

525

526

527

528

529

530

531

532

533

534

535

Greenstone, M. H., \& Hunt, J. H. (1993). Determination of prey antigen half-life in Polistes metricus using a monoclonal antibody-based immunodot assay. Entomologia Experimentalis et Applicata, 68(1), 1-7. https://doi.org/10.1111/j.1570-7458.1993.tb01682.x

Greenstone, M. H., Payton, M. E., Weber, D. C., \& Simmons, A. M. (2014). The detectability half-life in arthropod predator-prey research: what it is, why we need it, how to measure it, and how to use it. Molecular Ecology, 23(15), 3799-3813. https://doi.org/10.1111/mec.12552

Greenstone, M. H., Rowley, D. L., Weber, D. C., Payton, M. E., \& Hawthorne, D. J. (2007). Feeding mode and prey detectability half-lives in molecular gut-content analysis: an example with two predators of the Colorado potato beetle. Bulletin of Entomological Research, 97(2), 201-209. https://doi.org/10.1017/S000748530700497X

Hansen, J. E., \& New, T. R. (2005). Use of barrier pitfall traps to enhance inventory surveys of epigaeic Coleoptera. Journal of Insect Conservation, 9(2), 131-136.

https://doi.org/10.1007/s10841-004-5537-4

Harper, G. L., King, R. A., Dodd, C. S., Harwood, J. D., Glen, D. M., Bruford, M. W., \& Symondson, W. O. C. (2005). Rapid screening of invertebrate predators for multiple prey DNA targets. Molecular Ecology, 14(3), 819-827. https://doi.org/10.1111/j.1365-

294X.2005.02442.x

Harwood, J. D., Bostrom, M. R., Hladilek, E. E., Wise, D. H., \& Obrycki, J. J. (2007). An order-specific monoclonal antibody to Diptera reveals the impact of alternative prey on spider feeding behavior in a complex food web. Biological Control, 41(3), 397-407.

https://doi.org/10.1016/j.biocontrol.2007.02.008

Hatteland, B. A., Symondson, W. O. C., King, R. A., Skage, M., Schander, C., \& Solhøy, T. (2011). Molecular analysis of predation by carabid beetles (Carabidae) on the invasive Iberian slug Arion lusitanicus. Bulletin of Entomological Research, 101(6), 675-686. https://doi.org/10.1017/S0007485311000034

Hillocks, R. J. (2012). Farming with fewer pesticides: EU pesticide review and resulting challenges for UK agriculture. Crop Protection, 31(1), 85-93.

https://doi.org/10.1016/j.cropro.2011.08.008

Holland, J. M., \& Luff, M. L. (2000). The Effects of Agricultural Practices on Carabidae in Temperate Agroecosystems. Integrated Pest Management Reviews, 5(2), 109-129. https://doi.org/10.1023/A:1009619309424

Holland, J. M., \& Thomas, S. R. (2000). Do polyphagous predators help control orange wheat blossom midge, Sitodiplosis mosellana Gehin (Dipt.,Cecidomyiidae) in winter wheat? Journal of Applied Entomology, 124(7-8), 325-330. https://doi.org/10.1046/j.1439-

0418.2000.00478.x

Hoogendoorn, M., \& Heimpel, G. E. (2001). PCR-based gut content analysis of insect predators: Using ribosomal ITS-1 fragments from prey to estimate predation frequency. Molecular Ecology, 10(8), 2059-2067. https://doi.org/10.1046/j.1365-294X.2001.01316.x

Hoy, M. A. (1994). Insect molecular genetics : an introduction to principles and applications. San Diego : Academic Press. Retrieved from http://trove.nla.gov.au/version/13771494 
553

554

555

556

557

558

559

560

561

562

563

564

565

566

567

568

569

570

571

572

573

574

575

576

577

578

579

580

581

582

583

584

585

586

Ingels, B., Aebi, A., Hautier, L., Van Leeuwan, T., \& De Clercq, P. (2013). Molecular analysis of the gut contents of Harmonia axyridis (Coleoptera: Coccinellidae) as a method for detecting intra-guild predation by this species on aphidophagous predators other than coccinellids. European Journal of Entomology, 110(4), 567-576.

Juen, A., \& Traugott, M. (2004). Detecting predation and scavenging by DNA gut-content analysis: a case study using a soil insect predator-prey system. Oecologia, 142(3), 344-352. https://doi.org/10.1007/s00442-004-1736-7

Juen, A., \& Traugott, M. (2006). Amplification facilitators and multiplex PCR: Tools to overcome PCR-inhibition in DNA-gut-content analysis of soil-living invertebrates. Soil Biology and Biochemistry, 38(7), 1872-1879. https://doi.org/10.1016/j.soilbio.2005.11.034

King, R. A., Moreno-Ripoll, R., Agustí, N., Shayler, S. P., Bell, J. R., Bohan, D. A., \& Symondson, W. O. C. (2010). Multiplex reactions for the molecular detection of predation on pest and nonpest invertebrates in agroecosystems. Molecular Ecology Resources, 11(2), 370-373. https://doi.org/10.1111/j.1755-0998.2010.02913.x

King, R. A., Read, D. S., Traugott, M., \& Symondson, W. O. C. (2008). Molecular analysis of predation: a review of best practice for DNA-based approaches. Molecular Ecology, 17(4), 947-963. https://doi.org/10.1111/j.1365-294X.2007.03613.x

Kogan, M. (1998). Integrated Pest Management: Historical Perspectives and Contemporary Developments. Annual Review of Entomology, 43(1), 243-270.

https://doi.org/10.1146/annurev.ento.43.1.243

Kromp, B. (1999). Carabid beetles in sustainable agriculture: a review on pest control efficacy, cultivation impacts and enhancement. Agriculture, Ecosystems \& Environment, 74(1-3), 187-228. https://doi.org/10.1016/S0167-8809(99)00037-7

Landis, D. A., Wratten, S. D., \& Gurr, G. M. (2000). Habitat Management to Conserve Natural Enemies of Arthropod Pests in Agriculture. Annual Review of Entomology, 45(1), 175-201. https://doi.org/10.1146/annurev.ento.45.1.175

Lang, A. (2003). Intraguild interference and biocontrol effects of generalist predators in a winter wheat field. Oecologia, 134(1), 144-153. https://doi.org/10.1007/s00442-002-1091-5

Lövei, G. L., \& Sunderland, K. D. (1996). Ecology and behavior of ground beetles (Coleoptera: Carabidae). Annual Review of Entomology, 41, 231-256. https://doi.org/10.1146/annurev.en.41.010196.001311

Luff, M. L. (2002). Carabid assemblage organization and species composition. In The Agroecology of Carabid Beetles. Andover, UK: Intercept.

Luff, M. L. (2007). The Carabidae (2nd edition edition). St. Albans: Royal Entomological Society.

Lundgren, J. G., Ellsbury, M. E., \& Prischmann, D. A. (2009). Analysis of the predator community of a subterranean herbivorous insect based on polymerase chain reaction. Ecological Applications, 19(8), 2157-2166. https://doi.org/10.1890/08-1882.1 
587 Lys, J.-A. (1995). Observation of epigeic predators and predation on artificial prey in a cereal 588 field. Entomologia Experimentalis et Applicata, 75(3), 265-272. Mair, J., \& Port, G. R. (2001). Predation by the carabid beetles Pterostichus madidus and Agricultural and Forest Entomology, 3(2), 99-106. https://doi.org/10.1046/j.14619563.2001.00093.x

Matcham, E. J., \& Hawkes, C. (1985). Field assessment of the effects of deltamethrin on polyphagous predators in winter wheat. Pesticide Science, 16(4), 317-320.

https://doi.org/10.1002/ps.2780160402

Monzó, C., Sabater-Muñoz, B., Urbaneja, A., \& Castañera, P. (2011). The ground beetle Pseudophonus rufipes revealed as predator of Ceratitis capitata in citrus orchards. Biological Control, 56(1), 17-21. https://doi.org/10.1016/j.biocontrol.2010.09.004

Mowat, D. J. (Department of A. Z., \& Martin, S. J. (1981). The contribution of predatory beetles (Coleoptera: Carabidae and Staphylinidae) and seed-bed-applied insecticide to the control of cabbage root fly, Delia brassicae (Wied.), in transplanted cauliflowers [UK]. Horticultural Research (UK).

Naranjo, S. E. (2001). Conservation and evaluation of natural enemies in IPM systems for Bemisia tabaci. Crop Protection, 20(9), 835-852. https://doi.org/10.1016/S02612194(01)00115-6

Navntoft, S., Esbjerg, P., \& Riedel, W. (2006). Effects of reduced pesticide dosages on carabids (Coleoptera: Carabidae) in winter wheat. Agricultural and Forest Entomology, 8(1), 57-62. https://doi.org/10.1111/j.1461-9555.2006.00282.x

Nijveldt, W. C., \& Hulshoff, A. J. A. (1968). Waarnemingen inzake de tarwestengelgalmug (Haplodiplosis equestris Wagner) in Nederland. Centrum voor Landbouwpublikaties en Landbouwdocumentatie.

Öberg, S., Cassel-Lundhagen, A., \& Ekbom, B. (2011). Pollen beetles are consumed by ground- and foliage-dwelling spiders in winter oilseed rape. Entomologia Experimentalis et Applicata, 138(3), 256-262. https://doi.org/10.1111/j.1570-7458.2011.01098.x

Östman, Ö., Ekbom, B., \& Bengtsson, J. (2003). Yield increase attributable to aphid predation by ground-living polyphagous natural enemies in spring barley in Sweden. Ecological Economics, 45(1), 149-158. https://doi.org/10.1016/S0921-8009(03)00007-7

Penney, M. M. (1966). Studies on Certain Aspects of the Ecology of Nebria brevicollis (F.) (Coleoptera, Carabidae). Journal of Animal Ecology, 35(3), 505-512.

https://doi.org/10.2307/2488

Popov, C., Petcu, L., \& Barbulescu, A. (1998). Researches on biology, ecology and control of saddle gall midge (Haplodiplosis marginata von Roser) in Romania. Romanian Agricultural Research, (9), 67-73.

R Core Team. (2016). R: A Language and Environment for Statistical Computing. R Foundation for Statistical Computing, Vienna, Austria. 
640 Regulation (EC) No 1107/2009. (2009). Regulation of the European Parliament and of the 641 Council of 21 October 2009 concerning the placing of plant protection products on the market European Union L309, 1-50.

Rougerie, R., Smith, M. A., Fernandez-Triana, J., Lopez-Vaamonde, C., Ratnasingham, S., \& Hebert, P. D. N. (2011). Molecular analysis of parasitoid linkages (MAPL): gut contents of adult parasitoid wasps reveal larval host. Molecular Ecology, 20(1), 179-186. https://doi.org/10.1111/j.1365-294X.2010.04918.x

Rowley, C., Cherrill, A., Leather, S., Nicholls, C., Ellis, S., \& Pope, T. (2016). A review of the biology, ecology and control of saddle gall midge, Haplodiplosis marginata (Diptera: Cecidomyiidae) with a focus on phenological forecasting. Annals of Applied Biology, 169(2), 167-179. https://doi.org/10.1111/aab.12301

Rowley, C., Pope, T. W., Cherrill, A., Leather, S. R., Fernández-Grandon, G. M., \& Hall, D. R. (2017). Development and optimisation of a sex pheromone lure for monitoring populations of saddle gall midge, Haplodiplosis marginata. Entomologia Experimentalis et Applicata, 163(1), 82-92. https://doi.org/10.1111/eea.12560

Schmidt, J. M., Harwood, J. D., \& Rypstra, A. L. (2012). Foraging activity of a dominant epigeal predator: molecular evidence for the effect of prey density on consumption. Oikos, 121(11), 1715-1724. https://doi.org/10.1111/j.1600-0706.2011.20366.x

Sheppard, S. K., Bell, J., Sunderland, K. D., Fenlon, J., Skervin, D., \& Symondson, W. O. C. (2005). Detection of secondary predation by PCR analyses of the gut contents of invertebrate generalist predators. Molecular Ecology, 14(14), 4461-4468. https://doi.org/10.1111/j.1365-294X.2005.02742.x

Simon, C., Frati, F., Beckenbach, A., Crespi, B., Liu, H., \& Flook, P. (1994). Evolution, Weighting, and Phylogenetic Utility of Mitochondrial Gene Sequences and a Compilation of Conserved Polymerase Chain Reaction Primers. Annals of the Entomological Society of America, 87(6), 651-701. https://doi.org/10.1093/aesa/87.6.651

Sint, D., Raso, L., Kaufmann, R., \& Traugott, M. (2011). Optimizing methods for PCR-based analysis of predation. Molecular Ecology Resources, 11(5), 795-801.

https://doi.org/10.1111/j.1755-0998.2011.03018.x

Skuhravy, V. (1982). The saddle gall midge Haplodiplosis marginata (von Roser) (Diptera, Cecidomyiidae), an important pest of wheat and barley in Czechoslovakia. Folia Facultatis Scientiarum Naturalium Universitatis Purkynianae Brunensis, Biologia, 23(7), 133-135.

Skuhravý, V., Skuhravá, M., \& Brewer, T. W. (1993). The saddle gall midge Haplodiplosis marginata (Diptera: Cecidomyiidae) in Czech Republic and Slovak Republic from 1971-1989. Acta Societatis Zoologicae Bohemoslovacae, 57(2), 117-137.

Snyder, W. E., \& Wise, D. H. (1999). Predator Interference and the Establishment of Generalist Predator Populations for Biocontrol. Biological Control, 15(3), 283-292. https://doi.org/10.1006/bcon.1999.0723

Speyer, W., \& Waede, M. (1956). Feinde und Parasiten der Weizengallmücken. Anzeiger für Schädlingskunde, 29(12), 185-191. https://doi.org/10.1007/BF02672618 
693

694

695

696

697

698

699

700

701

702

703

704

705

706

707

708

709

710

711

712

713

714

715

716

717

718

719

720

721

722

723

724

725

726

727

728

729

730

731

732

733

734

735

736

737

738

739

740

741

742

743

744

745
Stuart, M. K., \& Greenstone, M. H. (1990). Beyond Elisa: a Rapid, Sensitive, Specific Immunodot Assay for Identification of Predator Stomach Contents. Annals of the Entomological Society of America, 83(6), 1101-1107. https://doi.org/10.1093/aesa/83.6.1101

Sunderland, K. D., Lovei, G. L., \& Fenlon, J. (1995). Diets and Reproductive Phenologies of the Introduced Ground Beetles Harpalus Affinis and Clivina Australasiae (Coleoptera, Carabidae) in New-Zealand. https://doi.org/10.1071/zo9950039

Sunderland, K., Powell, W., \& Symondson, W. (2005). Populations and Communites. In Insects as Natural Enemies: A Practical Perspective (pp. 299-434). Springer, Berlin, Germany.

Symondson, W. O. C. (2002). Molecular identification of prey in predator diets. Molecular Ecology, 11(4), 627-641. https://doi.org/10.1046/j.1365-294X.2002.01471.x

Theiling, K. M., \& Croft, B. A. (1988). Pesticide side-effects on arthropod natural enemies: A database summary. Agriculture, Ecosystems \& Environment, 21(3), 191-218. https://doi.org/10.1016/0167-8809(88)90088-6

van Toor, R. F. (2006). The effects of pesticides on Carabidae (Insecta: Coleoptera), predators of slugs (Mollusca: Gastropoda): literature review. New Zealand Plant Protection, $59,208-216$.

von Berg, K., Traugott, M., Symondson, W. O. C., \& Scheu, S. (2008). The effects of temperature on detection of prey DNA in two species of carabid beetle. Bulletin of Entomological Research, 98(3), 263-269. https://doi.org/10.1017/S0007485308006020

Waldner, T., Sint, D., Juen, A., \& Traugott, M. (2013). The effect of predator identity on postfeeding prey DNA detection success in soil-dwelling macro-invertebrates. Soil Biology and Biochemistry, 63, 116-123. https://doi.org/10.1016/j.soilbio.2013.03.030

Wilby, A., \& Thomas, M. B. (2002). Natural enemy diversity and pest control: patterns of pest emergence with agricultural intensification. Ecology Letters, 5(3), 353-360.

https://doi.org/10.1046/j.1461-0248.2002.00331.x

Woodville, H. C. (1970). Results of a Three Year Survey of Saddle Gall Midge (Haplodiplosis equestris (Wagn.) on Spring Barley. Plant Pathology, 19(3), 141-145.

https://doi.org/10.1111/j.1365-3059.1970.tb01003.x

Zhang, G.-F., Lü, Z.-C., Wan, F.-H., \& Lövei, G. L. (2007). Real-time PCR quantification of Bemisia tabaci (Homoptera: Aleyrodidae) B-biotype remains in predator guts. Molecular Ecology Notes, 7(6), 947-954. https://doi.org/10.1111/j.1471-8286.2007.01819.x 
746

747

748

749

750

751

752

753

754

755

756

757

758

759

760

761

762

763

764

765

766

767

768

769

770

771

772

773

774

775

776

777

778

779

780

781

782

783

784

785

786

787

788

789

790

791

792

793

794

795

796

797

798

List of figure legends

Figure 1. Proportion of positive assays for Haplodiplosis marginata DNA in the guts of Nebria brevicollis at time post-consumption of a single prey larva. Fitted line represents probit model with $95 \% \mathrm{Cl}$. 
800

801

802

803

804

805

806

807

808

809

810

811

812

813

814

815

816

817

818

819

820

821

822

823

824

825

826

827

828

829

830

List of table headings

Table 1. Species tested using the Haplodiplosis marginata primers and general insect primers to assess for cross-reactivity with non-target taxa. All species tested negative.

Table 2. Number of individuals of each carabid species tested for the presence of $H$. marginata DNA during the field survey in Buckinghamshire, UK, and expressed as a percentage of the total carabids tested (in brackets). Number of individual assays testing positive for the presence of $H$. marginata for each carabid species tested and the percentage positive for that species (in brackets).

(1)

(1) 
831 Table 1.

\begin{tabular}{|c|c|c|}
\hline Order & Family & Species \\
\hline \multirow[t]{14}{*}{ Coleoptera } & Nitidulidae & Meligethes sp. \\
\hline & Coccinellidae & Harmonia axyridis \\
\hline & Carabidae & Poecilus versicolor \\
\hline & & Poecilus cupreus \\
\hline & & Nebria brevicollis \\
\hline & & Pterostichus \\
\hline & & melanarius \\
\hline & & Anchomenus dorsalis \\
\hline & & Bembidion deletum \\
\hline & & Bembidion tetracolum \\
\hline & & Harpalus rufipes \\
\hline & & Harpalus affinis \\
\hline & & Abax parallelepipedus \\
\hline & & Loricera pilicornis \\
\hline \multirow[t]{15}{*}{ Diptera } & Cecidomyiidae & Sitodiplosis mosellana \\
\hline & Dolichopodidae & Undetermined sp. 1 \\
\hline & & Undetermined sp. 2 \\
\hline & Tachinidae & Undetermined \\
\hline & Syrphidae & Undetermined sp. 1 \\
\hline & & Undetermined sp. 2 \\
\hline & & Undetermined sp. 3 \\
\hline & & Undetermined sp. 4 \\
\hline & Tephritidae & Undetermined \\
\hline & Calliphoridae & Undetermined \\
\hline & Anthomyiidae & Undetermined \\
\hline & Drosophilidae & Undetermined sp. 1 \\
\hline & & Undetermined sp. 2 \\
\hline & Muscidae & \\
\hline & Undetermined & Undetermined \\
\hline \multirow[t]{4}{*}{ Hemiptera } & Aphididae & Sitobian avenae \\
\hline & & Myzus persicae \\
\hline & & Aphis fabae \\
\hline & & Rhopalosiphum padi \\
\hline \multirow[t]{4}{*}{ Hymenoptera } & Undetermined & Undetermined sp. 1 \\
\hline & & Undetermined sp. 2 \\
\hline & & Undetermined sp.3 \\
\hline & & Undetermined sp.4 \\
\hline \multirow[t]{2}{*}{ Symphypleona } & Undetermined & Undetermined sp. 1 \\
\hline & & Undetermined sp. 2 \\
\hline \multirow[t]{2}{*}{ Araneae } & Undetermined & Undetermined sp. 1 \\
\hline & & Undetermined sp. 2 \\
\hline
\end{tabular}

832 
833 Table 2.

834

\begin{tabular}{l|l|l}
\multicolumn{1}{c|}{ Species } & \multicolumn{1}{|c|}{$\begin{array}{c}\text { Number tested } \\
\text { (\% of total carabids) }\end{array}$} & $\begin{array}{l}\text { Number positive } \\
\text { (\% for species) }\end{array}$ \\
\hline Poecilus versicolor & $45(40.9)$ & $2(4.44)$ \\
Poecilus cupreus & $9(8.18)$ & $0(0)$ \\
Nebria brevicollis & $15(13.64)$ & $3(20)$ \\
Pterostichus melanarius & $6(5.45)$ & $0(0)$ \\
Anchomenus dorsalis & $1(0.91)$ & $0(0)$ \\
Bembidion deletum & $2(1.82)$ & $0(0)$ \\
Bembidion tetracolum & $1(0.91)$ & $0(0)$ \\
Harpalus rufipes & $19(17.27)$ & $2(10.53)$ \\
Harpalus affinis & $9(8.18)$ & $0(0)$ \\
Abax parallelepipedus & $1(0.91)$ & $0(0)$ \\
Loricera pilicornis & $2(1.82)$ & $1(50)$ \\
\hline Total & $110(100)$ & $8(7.27)$ \\
& &
\end{tabular}

835 